\title{
Control of mercury emissions: policies, technologies, and future trends
}

This article was published in the following Dove Press journal:

Energy and Emission Control Technologies

21 December 2015

Number of times this article has been viewed

\section{Seung-Whee Rhee \\ Department of Environmental Engineering, Kyonggi University, Suwon, Republic of Korea}

Correspondence: Seung-Whee Rhee Department of Environmental Engineering, Kyonggi University, I54-42 Gwanggyo-ro, Yeongtong-gu, Suwon 443-760, Republic of Korea Tel +82 3I 2499736

Fax +8231258 II 65

Email swrhee@kyonggi.ac.kr

\begin{abstract}
Owing to the Minamata Convention on Mercury and the Global Mercury Partnership, policies and regulations on mercury management in advanced countries were intensified by a mercury phaseout program in the mercury control strategy. In developing countries, the legislative or regulatory frameworks on mercury emissions are not established specifically, but mercury management is designed to prevent the emission of mercury. Nevertheless, the scenarios from global mercury observation system reported that mercury emissions from selected anthropogenic sources could be estimated to decrease by about $50 \%$ by 2020 . Advanced control technologies, which can be classified as hardware and software, can be applied to reduce mercury emission from anthropogenic sources. Among hardware technologies, pretreatment technology may be more important than recovery technology and treatment technology to reduce the mobility and toxicity of the materials containing mercury. Software technologies such as educational programs, monitoring systems, material flow analysis for mercury and mercury compounds, and life-cycle analysis to reduce mercury emissions are important to raise awareness of the significance of emission reduction. Finally, future trends of mercury control technologies and monitoring systems are discussed, along with the change in technical guidelines for the mercury emission control, both locally and globally.
\end{abstract}

Keywords: mercury source, policy and regulation, management program, control technology, mercury emission

\section{Introduction}

Recently, the Minamata Convention on Mercury was adopted unanimously to be a global treaty to protect human health and the environment from anthropogenic emissions and releases of mercury and mercury compounds. ${ }^{1-3}$ Until July 2014, 101 countries signed the Convention to ban new mercury mines, the phaseout of existing ones, control measures on air emissions, and the international regulation of the informal sector for artisanal and small-scale gold mining. The emergence of the Minamata Convention on mercury was due to the appearance of a new disease (Minamata disease) among residents in the Minamata Bay, Japan, in 1956, which became the most notorious outbreak of mercury pollution in the world. ${ }^{4-6}$

Since mercury is a toxic and ubiquitous metal that has broad uses in various fields, the control of mercury emissions throughout its cycling in the ecosystem has been a most important factor in the developing countries to prevent its toxic effects on the environment and human health. Several countries have been involved in preparing the control policy and guidelines to reduce the use of mercury. Technical guidelines for the environmentally sound management of wastes consisting of elemental mercury 
and wastes containing or contaminated with mercury were prepared by the open-ended working group of the Basel Convention in 2011 . $^{7}$

In USA, the Mercury Export Ban Act was signed into law in 2008 and was activated from 2013. Because the US was ranked as one of the world's top exporters of mercury, the implementation of the act will remove a significant amount of mercury from the global market. Mercury has been exported from the US to foreign countries, where it has various uses, including its use in artisanal and small-scale gold mining. The use of mercury in artisanal gold mining not only adversely affects the health of millions of artisanal miners and their communities, but is also a major cause of global mercury pollution. ${ }^{8}$ In the European Union (EU) framework, an export ban of metallic mercury and certain compounds and mixtures to non-EU countries was activated in 2011, and the requirements for temporary mercury waste storage were defined by an EU directive in 2011. ${ }^{9-11}$ United Nations Environment Programme (UNEP) proposed an overarching framework for a global mercury partnership between governments and other stakeholders as one approach to reduce the risk for human health and the environment from the release of mercury and its compounds to the environment. ${ }^{12,13}$ In Asian countries, including the People's Republic of China, Japan, Korea, and the Philippines, the management of mercury and mercury compounds was undertaken through measurement and control the emission of mercury in the environment by regulations or guidelines on mercury-containing products.

In this study, sources of mercury were initially reviewed to assess the contributions from anthropogenic sources and natural sources. The emission of mercury from the sources is evaluated by measuring these amounts of mercury globally and by analyzing the flow of mercury and mercury compounds. The policies and regulations in each country are discussed to manage mercury emissions properly, and policy integration for mercury management among countries may be beneficial to prevent the emission of mercury. Mercury control technologies such as pretreatment technology, recovery technology, and treatment technology are discussed to reduce the emission of mercury from various sources. Finally, future trends of mercury control technologies are reviewed by raising the mercury issue in the world.

\section{Sources of mercury emission}

Mercury emissions mainly come from two types of sources: natural and anthropogenic. ${ }^{2,14-17}$ Natural sources can be described as mercury released from the Earth's crust by the continuous and ubiquitous natural weathering of mercury-containing rocks or by geothermal activity, or mercury emitted during episodic events such as volcanic eruptions. Anthropogenic sources can be expressed as mercury released as a result of human activities, such as burning fuels, and raw materials in industrial processes.

\section{Mercury emissions from natural sources}

Mercury emissions from natural sources can be contributed by primary natural sources and reemission sources. Mercury emitted from oceans, forest fires, ${ }^{18-21}$ volcanoes, and geothermal areas ${ }^{22-24}$ enriched in mercury pertains to primary natural sources, whereas the reemission of previously deposited mercury on land or water surfaces ${ }^{25-27}$ is primarily related to land usage, biomass burning, and meteorological conditions. ${ }^{15,28}$

The mercury emissions from primary sources and reemissions were estimated to be 5,207 ton/year (yr). ${ }^{14,28,31}$ Oceans are the most important sources $(52 \%)$, followed by biomass burning (13\%), deserts and nonvegetated zones $(10 \%)$, tundra and grassland $(9 \%)$, and forests $(7 \%)$. Specifically, more than $60 \%$ of the world mercury reserves are in the cinnabar belt underlying the Mediterranean area, which covers only about $1 \%$ of the world oceans. Mercury in the Mediterranean area mostly came from former mining activities, coal and oil combustion, cement production, and chlor-alkali plants during the past decades. ${ }^{29}$ Overall, the emission from land surfaces $(2,429$ ton/yr) is higher than that from water surface $(2,778 \mathrm{ton} / \mathrm{yr})$, even though the area of land surface (area, $1.46 \times 108 \mathrm{~km}^{2}$ ) is smaller than that of water surface (area, $3.49 \times 108 \mathrm{~km}^{2}$ ). According to Mason et al, ${ }^{30}$ total annual mercury emissions into the atmosphere have been variously estimated at between 5,500 and 8,900 ton/yr. Mercury emissions into the atmosphere from natural sources are estimated at 80-600 ton/yr, and reemissions from soils and vegetation and from oceans are estimated at 1,700-2,800 and 2,000-2,950 ton/yr, respectively. Hence, mercury emissions from natural sources may range between 3,780 and 6,350 ton/yr.

\section{Mercury emission from anthropogenic sources}

More recently, assessments of mercury emissions into the global atmosphere have included the contribution of the most important anthropogenic sources. ${ }^{16,28}$ The main categories of the most important anthropogenic sources of mercury emissions can be classified into three emission groups: emissions from mobilization of mercury impurities, emissions from intentional extraction and use of mercury, and emissions 
from waste treatments, as shown in Table $1 .^{14,15,31}$ Mercury emissions into the atmosphere from a large number of human activities, including coal burning, ferrous and nonferrous metal-manufacturing facilities, consumer production waste, contaminated sites, chlor-alkali industry, cement production plants, and gold mining, were estimated to be approximately 1,960 tons $(1,010-4,070$ tons $)$ in $2010 .{ }^{16}$

The major source of emissions into the atmosphere was coal burning, emitting some 474 tons of mercury into the atmosphere annually, compared with around 10 tons from combustion of other fossil fuels. More than $85 \%$ of mercury emissions are from coal burning in power generation and industrial uses. Industrial activities such as chlor-alkali processing and metal processing, incineration of coal, medical and other waste, and gold mining contribute greatly to mercury emission into the atmosphere because mercury can exist as an impurity in fuels and raw materials in industrial processes. Although mercury is a potent neurotoxin that poses risks to human health, it is still used in a wide range of products, including batteries, paints, switches, electrical and electronic devices, thermometers, blood-pressure gauges, fluorescent and energy-saving lamps, pesticides, fungicides, medicines, and cosmetics. From these products containing mercury, mercury waste that can be generated and treated by an incinerator can be a major source of atmospheric mercury.

Mercury emissions from the EU and North and South Americas contributed about $20 \%$ of the global total. The

Table I The classification of major generator for mercury emissions

\begin{tabular}{|c|c|c|}
\hline Industry & Household & $\begin{array}{l}\text { Treatment } \\
\text { facilities }\end{array}$ \\
\hline Coal and oil combustion & Batteries & $\begin{array}{l}\text { Municipal waste } \\
\text { combustion }\end{array}$ \\
\hline Cement production & $\begin{array}{l}\text { Measuring and control } \\
\text { devices }\end{array}$ & $\begin{array}{l}\text { Hazardous waste } \\
\text { incinerators }\end{array}$ \\
\hline \multirow[t]{2}{*}{$\begin{array}{l}\text { Iron-steel manufactures } \\
\text { (electric arc furnaces) }\end{array}$} & Electronic devices & $\begin{array}{l}\text { Medical waste } \\
\text { incinerators }\end{array}$ \\
\hline & Lighting lamp & $\begin{array}{l}\text { Sewage sludge } \\
\text { incinerators }\end{array}$ \\
\hline $\begin{array}{l}\text { Primary and secondary } \\
\text { non-ferrous metal } \\
\text { production }\end{array}$ & Dental use and amalgam & Landfill treatment \\
\hline $\begin{array}{l}\text { Artisanal and small scale } \\
\text { gold and silver mining }\end{array}$ & Paint and pesticides & $\begin{array}{l}\text { Wastewater } \\
\text { treatment process }\end{array}$ \\
\hline $\begin{array}{l}\text { Caustic soda production } \\
\text { (chlor-alkali plants) }\end{array}$ & Plasticizers & $\begin{array}{l}\text { Mercury in waste } \\
\text { derived from } \\
\text { industrial facilities }\end{array}$ \\
\hline $\begin{array}{l}\text { Mercury mining and } \\
\text { production }\end{array}$ & Soap and cosmetics & $\begin{array}{l}\text { Other waste } \\
\text { treatments }\end{array}$ \\
\hline
\end{tabular}

largest atmospheric mercury emission from anthropogenic sources came from Asia, which contributed more than $45 \%$ of the global total. Mercury emissions from East and Southeast Asia were estimated to be 777 ton/yr. The People's Republic of China has been regarded as one of the great mercury emitters from a global perspective ${ }^{2,16,32-37}$ due to rapid economic development. The majority of the mercury emissions were generated from the combustion of fossil fuels. Because coal combustion was the main source of energy in the People's Republic of China, the mercury emissions were high and the mercury concentrations in the atmosphere were increased.

The top five countries to use oil for generating electric power were the USA, Japan, Russia, People's Republic of China, and Germany. The distillate and residual oils are used by electric utilities and industrial and residential boilers. These oils contain mercury as an impurity, with concentrations that vary with the crude oil type. The mercury concentrations in crude oil range from 0.007 to $30 \mathrm{mg} / \mathrm{kg}$, with a typical value being $3.5 \mathrm{mg} / \mathrm{kg}$. ${ }^{31,38,39}$ The mercury emissions from the top five countries that produce electric power by crude oils significantly contribute to the total atmospheric emissions as anthropogenic sources. As the use of fossil fuels such as coal and crude oil is increasing in order to meet the growing energy demands of both developing and developed nations, mercury emissions can be expected to increase.

\section{Policy and regulation on mercury management Policy and regulation on mercury management in EU}

Current mercury emissions in Europe are estimated to be about 145 ton/yr, of which coal and lignite combustions in power plants are major sources accounting for more than $60 \%$ of the anthropogenic mercury emissions. Different policies for mercury management are applied for EU countries and non-EU countries. In the EU countries, air quality measures further reduce mercury emissions by $35 \%$, but emissions in non-EU countries increase with industrial activities because of a lack of additional air pollution control.

The EU has made valuable achievements in announcing the global challenges of mercury since it undertook the EU mercury strategy in 2005. ${ }^{9,40}$ In the strategy, the main objectives can be described as reducing mercury emission, restrictions on selling mercury-containing products, ban on export of mercury from the EU, and safe storage of mercury. 
The reduction and phaseout of mercury in products and industrial processes is one of the most effective ways to reduce mercury emissions. Hence, the EU countries should develop and enforce a legislative or regulatory framework for a phaseout program establishing a cutoff date for banning the use of mercury in products and processes (except for those for which there are no technically or practically viable alternatives or exemptions). This approach encourages largescale users and producers of mercury and mercury-containing products to comply with the requirement to embark on a mercury phaseout program. In certain cases, it may be useful to complement the phaseout program with a ban on the export of wastes.

In order to achieve the objectives of its mercury strategy, the EU has been applied restrictions on the use of certain hazardous substances in electrical and electronic equipment. ${ }^{41,42}$ The WEEE Directive is designed to prevent the generation of electronic waste by increasing recycling and producer responsibility. ${ }^{45}$ RoHS (The Restriction of the Use of Hazardous Substances in Electrical and Electronic Equipment) Directive has strictly limited mercury-containing electrical and electronic equipment, and has implemented the phaseout of such equipment in the EU market since 2006. ${ }^{44}$

In implementing the EU mercury strategy, ${ }^{3,9,16}$ a number of restrictions on the use of mercury in products have been imposed. Owing to the restrictions on mercury discharge from waste incineration plants (2000), the discharge standard of mercury was set at $0.05 \mathrm{mg} / \mathrm{m}^{3}$ for new facilities and $0.1 \mathrm{mg} / \mathrm{m}^{3}$ for existing facilities. A framework for phaseout production is applied on the restriction of the use of waste batteries and accumulators. All batteries that contain more than $0.0005 \mathrm{wt} \%$ of mercury are prohibited from being placed on the market, subject to exemptions (this ban is not applicable to button cells, which have a mercury content of no more than $2 \mathrm{wt} \%$ ). Mercury in several measuring devices (eg, thermometers, sphygmomanometers, barometers) was banned from use by the general public and for industrial and professional usage concerning the Registration, Evaluation, Authorisation and Restriction of Chemicals (REACH) in 2014. ${ }^{44}$ Commission Regulation in the EU prohibits the manufacture and placement on the market of five phenylmercury compounds from 2017. As part of the management of mercury-containing products, sales of products containing more than $5 \mathrm{mg}$ of mercury and sales of mercury-containing medical equipment have been prohibited from 2008. ${ }^{43}$

The EU mercury strategy includes a comprehensive plan addressing mercury pollution both in the EU and globally. The EU is pushing for more extensive controls on mercury in goods and international commerce by the banning of mercury exports and the safe storage of metallic mercury. A ban on exports of mercury from the EU came into force from 2011, and so were new rules on the safe storage requirements of mercury and metallic mercury adopted in the mercury strategy. The specific criteria for temporary storage of metallic mercury should be considered as waste and the safe storage of mercury in chlor-alkali industry is no longer used. ${ }^{16}$

According to the amendment of landfill directive, liquid metallic mercury could be disposed by ensuring that its storage and final disposal is carried out safely. Metallic mercury may be stored temporarily ( $>1$ year) in aboveground storage or permanently in salt mines adapted or deep underground hard rock formations. For underground storage, specific safety assessment is prescribed due to the fact that leaching limit values do not apply. The acceptance of mercury content at each landfill type primarily depends on the leaching properties of the waste. The mercury content in the waste should be satisfied the leaching limit value by a standard leaching test for a specific type of landfill. ${ }^{45}$

\section{Policy and regulation on mercury management in North America}

The US has introduced a series of regulations to control mercury emissions from the Mercury Action Plan. ${ }^{46}$ Mercury is primarily managed under the Clean Air Act, which regulates hazardous air pollutants through a series of regulations and standards, including the National Emission Standards for Hazardous Air Pollutants (NESHAP), rules for iron foundries, steelmaking facilities, and chlor-alkali plants. A NESHAP rule is proposed for the Portland CementManufacturing Industry, which would significantly reduce mercury emissions from that sector. ${ }^{47}$

Mercury-Containing and Rechargeable Battery Management Act of 1996 was launched to phase out the use of mercury in batteries, and provided an efficient and cost-effective disposal of regulated batteries. ${ }^{48}$ The statute is applicable to battery and product manufacturers, battery waste handlers, and certain battery and product importers and retailers. In 2006, the United States Environmental Protection Agency (US EPA) implemented the National Vehicle Mercury Switch Recovery Program to collect mercury brake sensors and mercury switches in vehicles. The program aims to collect about $80 \%-90 \%$ of the mercury switches by 2017 . The US EPA planned to develop mercury emissions rules for coal- and oil-fired power plants by 2011 in order to prevent mercury emission into the atmosphere. ${ }^{49,50}$ 
The EPA's 2006 Roadmap for Mercury outlines further US actions in six areas: addressing mercury release into the environment, addressing mercury use in products and industrial processes, managing commodity-grade mercury supplies, communicating risks to the public, addressing international mercury sources, and conducting mercury research and monitoring. ${ }^{51,52}$ Mercury-containing equipment was controlled by the Universal Waste Act, to meet land disposal restrictions (LDR) treatment standards when treated, and be sent to treatment facilities. ${ }^{53,54}$

Furthermore, in 2008, the US Congress passed the Mercury Export Ban Act, which prohibits the export of elemental mercury from the US with effect from 2013. ${ }^{8}$ The act includes provisions on both mercury exports and long-term mercury management and storage. Since the US is ranked as one of the world's top exporters of mercury, implementing the act will help remove a significant amount of mercury from the global market.

Other acts such as the Clean Water Act and the Resource Conservation and Recovery Act support the effective management of mercury by using water quality standards and the control of waste stream from generation to disposal in the US. In the Toxic Substances Control Act, the EPA proposed a new rule for the use of elemental mercury in mercury-containing products such as switches/relays, button-cell batteries, and measuring devices. ${ }^{55}$ In the Safe Drinking Water Act, the EPA laid down some standards for drinking water that applied to public water systems. These standards have protected people by limiting the level of mercury and other contaminants in drinking water. ${ }^{56} \mathrm{In}$ order to reduce direct and indirect human exposure to mercury, the US Food and Drug Administration (FDA) has established controls on mercury in fish and in dental amalgam. ${ }^{57}$

Canada is also actively engaged in a number of programs associated with the mercury management by federal legislation and guidelines, various programs and research groups, and through participation in international initiatives. Provincial and territorial governments have also established tools for reducing the impact of mercury pollution by the Arctic Waters Pollution Prevention Act, the Canada Water Act, and the Canadian Environmental Protection Act. ${ }^{58}$

Canadian EPA established the Fisheries Act in 1985 to carry out fisheries protection and pollution prevention associated with Chlor-alkali Mercury Liquid Effluent Regulations. ${ }^{59}$ Guidelines for Canadian Drinking Water Quality on mercury were set to control mercury concentration in drinking water. And the criterion for identifying hazardous wastes based on the mercury concentration level is $0.1 \mathrm{mg} / \mathrm{L}$ by Toxicity
Characteristic Leaching Procedure (TCLP). Canada is currently developing regulations to reduce greenhouse gas emissions from coal-fired electricity generation to be launched in 2015. These regulations are expected to reduce mercury emissions from the electrical power generation sector by about $40 \%$ in 2020 and $65 \%$ in 2030, compared with 2005 levels, and could reduce mercury emissions by up to $96 \%$ in 2050 .

At the global level, Canada was a member of the Basel Convention and was engaged in developing Technical Guidelines for the Environmentally Sound Management of Wastes Consisting of, Containing or Contaminated with Mercury. ${ }^{7}$ Canada is also party to the Protocol on Heavy Metals to the United Nations Economic Commission for Europe's Convention on Long-range Transboundary Air Pollution, which aims to reduce emissions of mercury, lead, and cadmium from industrial sources, combustion processes, and waste incineration. In addition, Canada participates in the UNEP Global Mercury Programme and its Global Mercury Partnership, which aim to initiate early actions in a number of key sectors, such as coal combustion and artisanal and small-scale gold mining. ${ }^{16}$

\section{Policy and regulation on mercury management in Asia}

Recently, the People's Republic of China has reinforced its efforts to reduce and prevent pollution by mercury and other heavy metals through a number of laws, guidelines, and other measurements, including a mercury pollution monitoring system. The MEP (Ministry of Environmental Protection of the People's Republic of China) developed and revised technical policies, Best Available Technology (BAT) guidelines, and standards associated with the prevention of heavy metal pollution, specifically mercury emission. About 20 industrial standards for batteries and lamps applied to mercury production, consumption, and disposal activities. ${ }^{36,60}$

In 2011, the People's Republic of China approved the Heavy Metal Pollution Prevention and Control Plan (20112015), which focused on mercury, lead, cadmium, arsenic, and chromium, to solve prominent problems that impaired public health in the heavy metal-related industry. The MEP has provided Guidelines for the Formulation of Local Plan of Heavy Metal Pollution Prevention and Control to local governments, including mercury and mercury compounds. Although regulations, guidelines, and standards to control mercury emission have been established in the People's Republic of China, mercury management in the People's Republic of China is still at the initial stage. It will be essential 
to establish efficient and effective policies and regulations on the mercury pollution for prevention and control systems. ${ }^{61}$

In India, the National Rural Health Mission established the Infection Management and Environment Plan in 2007. ${ }^{62,63}$ There were two policies in the plan. The first policy was related to a broad overview and guidance on the type of systems and processes to be established for the management of infection waste and biomedical waste. The second policy was concerning a set of operational guidelines which were designed for health care workers at primary level health care facilities. Both these policies have integrated mercury spill management and also advised the health care establishments to eventually start a phaseout plan for mercury-containing equipment. The Bureau of India Standards has decided the safety limits of mercury for drinking water at $0.001 \mathrm{mg} / \mathrm{L}$ and the limit for industrial effluents at $0.01 \mathrm{mg} / \mathrm{L}$. According to the Indian legislation, any solid waste with mercury concentration higher than $50 \mathrm{mg} / \mathrm{kg}$ is considered as a hazardous waste. ${ }^{64}$

The Department of Health and Family Welfare in India published reports on mercury, including the usage, breakage, and disposal patterns, in 2004 and on the presence of mercury in ambient air in 2007. The Department set up a Mercury Phaseout Committee to examine the reduction possibilities of mercury in health care facilities for mercury-free alternatives. The Delhi Pollution Control Committee (DPCC) and the Department of Environment, in a public notice in 2008. All hospitals were required to provide a template on its commitment to stop the use of mercury-containing equipment and eliminate mercury-containing wastes. ${ }^{41}$

In Japan, the policies and regulations on mercury have been the most sensitive issue in the world because of the Minamata disease. A number of initiatives/schemes/programs to deal with the various problems associated with the Minamata disease have been developed through the history of the disease, and many initiatives and measures have been introduced over a period of more than 50 years. ${ }^{65}$

Restrictions on mercury discharge based on the lessons learned from the Minamata disease case and other pollution issues have caused the use of mercury to decline. Owing to the development of new technologies to reduce the mercury use and to shift to mercury-free alternatives, its demand has declined drastically. Recently, the mercury demand in Japan was $\sim 10$ ton/yr, compared with $\sim 2,500$ ton/yr in 1964 .

In the Waste Management Act, Japan, the regulatory level of mercury concentration was subject to treatment standards for mercury-containing wastes. For untreated and treated ash, dust, mining sludge, and sludge, the regulatory level of mercury concentration was $0.005 \mathrm{mg} / \mathrm{L}$ in the leaching test, but alkyl mercury should not be detected. For waste acid and waste alkali as the special management industrial wastes, the regulatory level of mercury concentration was $0.05 \mathrm{mg} / \mathrm{L}$. Stricter regulations apply to the special management industrial wastes regarding transportation and treatment, compared to regular waste. The special management industrial wastes must be disposed of at a "shielded landfill", which is separated completely from public waterways, after proper treatment. ${ }^{66}$

In the Air Pollution Control Act, the guideline value for reducing health risks from hazardous air pollutants in the environment was less than $40 \mathrm{ng} / \mathrm{m}^{3}$ for mercury vapor (annual average). Under the Water Pollution Control Act, the effluent standard for mercury, alkyl mercury, and other mercury compounds was less than $0.005 \mathrm{mg} / \mathrm{L}$, and no detection of alkyl mercury compounds. According to the Basic Environment Act in Japan, the environmental quality standard for mercury for soil, public waterways, and groundwater was $0.0005 \mathrm{mg} / \mathrm{L}$, and no detection of alkyl mercury on annual average. ${ }^{67}$

In Korea, the Ministry of Environment established the first Comprehensive Plan and Countermeasures for Mercury Management in 2006. The objective of the first plan was to manage mercury-containing products from discharge of the product and to survey mercury emission. ${ }^{68}$ Through this plan, mercury management and mercury-related activities were implemented in Korea. To prepare the countermeasures for the Mercury Convention, the second Comprehensive Plan and Countermeasures for Mercury Management was established in 2010. The objective of the second plan was to build a foundation of the integrated mercury management. This plan was focused on the comprehensive mercury management through the life cycle of production, consumption, and discharge of mercury and mercury compounds.

Under the Clean Air Conservation Act in Korea, the regulatory level for atmospheric emission facilities was less than $0.1 \mathrm{mg} / \mathrm{m}^{3}$ for mercury vapor. Although the regulatory level for incineration facilities and thermoelectric plants was reduced from $5.0 \mathrm{mg} / \mathrm{m}^{3}$ to less than $0.1 \mathrm{mg} / \mathrm{m}^{3}$ in 2005 , it was relatively high compared to EU $\left(0.05 \mathrm{mg} / \mathrm{m}^{3}\right)$, Japan $\left(0.04 \mathrm{mg} / \mathrm{m}^{3}\right)$, and USA $\left(0.01 \mathrm{mg} / \mathrm{m}^{3}\right)$. In the Water Quality Conservation Act, the effluent quality standard for mercury was $0.001 \mathrm{mg} / \mathrm{L}$ for clean areas and $0.005 \mathrm{mg} / \mathrm{L}$ for other areas. According to the Soil Environment Conservation Act, the regulatory standard of soil was $4.0 \mathrm{mg} / \mathrm{kg}$ for school 
areas and historical places and $16.0 \mathrm{mg} / \mathrm{kg}$ for factory areas and roads. According to the Drinking Water Regulation, the regulatory standard was $0.001 \mathrm{mg} / \mathrm{L}$ in Korea. ${ }^{69}$

In the Waste Management Act, Korea, the regulatory mercury concentration for specific wastes was $0.005 \mathrm{mg} / \mathrm{L}$ in the leaching test. However, the regulatory mercury concentration for municipal solid wastes is not applied even though there is high mercury concentration in the wastes. Also, the regulatory mercury concentration has not been applied to mercury discharge from industrial waste treatment facilities. ${ }^{70}$ For spent fluorescent lamps (SFLs), the recycling facilities in Korea are located at four places. In 2011, the generation of SFLs was about 147 million tubes, but the recycling rate of SFL was only $28 \%$. Even though the recycling technology of SFL has been developed in Korea, the recycling equipment for SFLs in Korea is imported from the EU. The recycling processes of SFLs in Korea mainly focused on separation of phosphor powder from other materials because most mercury was contained in phosphor powder. Separation processes, such as air injection system, crushing and sieving process, will be applied to separate phosphor powder from glass tube. ${ }^{71,72}$

There is no specific policy on mercury management yet in several Asian countries such as Cambodia, Indonesia, and Vietnam. ${ }^{73}$ Only some other policies such as solid waste management and wastewater pollution control were activated in these countries. In these countries, wastes containing mercury were classified as hazardous wastes. According to wastewater pollution control (1999) of the Ministry of Environment in the Kingdom of Cambodia, the effluent standard of mercury in wastewater dumped into water body was $0.002 \mathrm{mg} / \mathrm{L}$ for protected public water area and $0.05 \mathrm{mg} / \mathrm{L}$ for public water area and sewer. In Indonesia, the existence of the small-scale gold mining activity was regulated by the Ministry of Environment through the technical guideline for the prevention of pollution and environmental damage. Most of the miners utilized the natural sources by simple methods of extraction and processing without considering their safety and the impact of their activities on the ecosystem. In Malaysia, contamination problems due to mercury wastes have been found in water bodies, in biota, and in the human body. ${ }^{74}$ Numerous papers have been published regarding the management of mercury. These address the sources of release and contamination of mercury in the Malaysian environment or in its commodities. The Vietnam government has paid more attention to the mercury management, undertaking initial investigations on mercury emission from industrial sector as well as from the health care sector. Also, Vietnam has officially joined the Minamata Convention on Mercury in order to control mercury systematically.

\section{Mercury control technology}

In order to recycle wastes and wastewater containing mercury, advanced procedures should be used to prevent any release of mercury into the environment. Additionally, the purity of recycled mercury should be high to sell on the commercial market effectively. Advanced control technology for the recycling of wastes and wastewater containing mercury can be classified into pretreatment technology, recovery technology, and treatment technology. ${ }^{7}$ Also, the recycling technologies can be applied to the various phases of mercury generation, such as gaseous phase, liquid phase, and solid phase. The elemental mercury in the gaseous phase may be stable to travel long distance without changing its characteristic. The soluble or oxidized mercury in the liquid phase may sustain mostly in water-soluble form, and the mercury in the solid phase may exist in various particle forms.

Pretreatment technology prior to the recovery operation of mercury wastes is very important to improve the purity of mercury. The better the pretreatment process applied, the higher the purity of mercury obtained. Hence, it is necessary to maximize the use of pretreatment for mercury materials before they are sent to the recovery operation process. The mercury as an impurity in this process can be physically separated from mercury-containing materials by simple filtration. In pretreatment technology, several processes are involved, such as screening, mechanical crushing, air separation, dewatering, extraction, and dismantling, to separate impurities from wastes and wastewater containing mercury, as shown in Table 2.,75-78

Recovery technology can be classified mainly into two divisions. The first recovery division aims to recover the materials containing mercury with chemical processes, and the second recovery division aims to recover the elemental mercury from the materials with thermal processes.

The first recovery division may be generally involved in chemical oxidation, ${ }^{79-83}$ chemical precipitation, and adsorption process, as shown in Table $3 .^{7,84,85}$ Chemical oxidation is carried out to destroy the organics and to convert as mercury salts. It is effective for treating aqueous waste containing or contaminated with mercury such as slurry and tailings ${ }^{84}$ Chemical precipitation is used to transform the dissolved or suspended form into an insoluble solid. Insoluble solids can be precipitated through processes such as coagulation and flocculation. The precipitated/coprecipitated solid can be then removed from the liquid phase by clarification or 
Table 2 Pretreatment methods of mercury-containing wastes

\begin{tabular}{|c|c|c|}
\hline Method & Explanation & Mercury waste \\
\hline Mechanical crushing & $\begin{array}{l}\text { Crushers may be used to reduce the size of materials so they can be more easily } \\
\text { and efficiently used in the recovery methods. Crushing is the process of transferring } \\
\text { a force amplified by mechanical advantage through a material made of molecules. }\end{array}$ & Lamp \\
\hline Air separation & $\begin{array}{l}\text { The objective of air separation is to classify the less-dense materials using air as } \\
\text { the fluid. Air flows into the glass cullet of fluorescent lamps from the bottom } \\
\text { to remove mercury-phosphor powder attached on glass. }\end{array}$ & Lamp, aluminum caps \\
\hline Removal of impurities & $\begin{array}{l}\text { The process of purification. If mercury-containing batteries are collected together } \\
\text { with other types of batteries or with waste electrical and electronic equipment, } \\
\text { mercury-containing batteries should be separated from other types of batteries. } \\
\text { Before thermal treatment, impurities adsorbed onto mercury-containing batteries } \\
\text { should be removed by mechanical process. }\end{array}$ & Batteries \\
\hline Dewatering & $\begin{array}{l}\text { Dewatering is the removal of water from solid material by wet classification, } \\
\text { filtration, centrifugation, or similar solid-liquid separation processes, such as } \\
\text { removal of residual liquid from a filter cake by a filter press as part of various } \\
\text { industrial processes. Sewage sludge contaminated with mercury needs to be } \\
\text { dewatered to about } 20 \%-35 \% \text { solids before any thermal treatment. }\end{array}$ & Sewage sludge \\
\hline Dismantling & $\begin{array}{l}\text { To take a piece of equipment (or machine) apart. Wastes containing mercury are } \\
\text { usually attached to electric devices. Therefore, such wastes should be removed } \\
\text { from the devices without breakage of the outer glass. }\end{array}$ & $\begin{array}{l}\text { Electric switches, } \\
\text { relays, LCD }\end{array}$ \\
\hline
\end{tabular}

filtration. Mercury or mercury compounds are adsorbed by passing a liquid or gaseous phase through a column which was filled with adsorption materials such as activated carbon and zeolite for mercury control. ${ }^{85-97}$
In the second recovery division, thermal method and distillation are used to evaporate and recover mercury with a cooling system. Thermal method is a process that transfers contaminants from one phase to another using boiling point.

Table 3 Recovery methods of mercury-containing wastes

\begin{tabular}{|c|c|c|}
\hline Method & Explanation & Mercury waste \\
\hline Thermal treatment & $\begin{array}{l}\text { Thermal desorption systems are physical separation processes that transfer } \\
\text { contaminants from one phase to another. } \\
\text { The process generally includes the following stages } \\
\text { a. Heating the input material in a special kiln or in a charging operation to evaporate } \\
\text { the mercury contained in the waste at temperatures between } 300^{\circ} \mathrm{C} \text { and } 400^{\circ} \mathrm{C} \text {. }\end{array}$ & $\begin{array}{l}\text { Sewage sludge, soil, waste, } \\
\text { lamps, thermometers, } \\
\text { batteries, dental amalgam, } \\
\text { electrical switches, mining } \\
\text { residues }\end{array}$ \\
\hline
\end{tabular}

Chemical oxidation Chemical oxidation of elemental mercury and organomercury compounds is carried out to destroy the organics and to convert mercury so that it forms mercury salts.

Slurry, tailings It is effective for treating liquid waste containing or contaminated with mercury. Oxidizing reagents used in these processes include sodium hypochlorite, ozone, hydrogen peroxide, chlorine dioxide, and free chlorine (gas).

Chemical precipitation Colloidal or suspended contaminants become enmeshed with other precipitated species or are removed through processes such as coagulation and flocculation. Processes to remove mercury from water can include a combination of precipitation and coprecipitation. The precipitated/coprecipitated solid is then removed from the liquid phase by clarification or filtration.

Adsorption treatment Adsorption materials hold mercury on the surface through various types of chemical forces such as hydrogen bonds, dipole-dipole interactions, and van der Waals forces.

Distillation of mercury - Distillation generates pure liquid mercury. In distillation, collected mercury is purification subsequently purified by successive distillation. High-purity mercury is produced by distillation in many steps, permitting a high purity grade to be achieved in each distillation step.

Extraction Extraction is a process of getting mercury by pulling it out with solvent. Elemental mercury contained in the products should be extracted, and the extracted elemental mercury is distilled for purification under reduced pressure. Acid extraction is an ex situ technology that uses an extracting chemical such as hydrochloric acid or sulfuric acid to extract contaminants from a solid matrix.

Contaminated water

Wastewater, all flue gases Enriched mercury wastes

Thermometer, barometer 
It means either indirect or direct heat consumption to increase the temperature to volatilize and separate mercury from mercury-contaminated materials. ${ }^{88-90}$ For mercury and its compounds, indirect thermal method may be recommended to collect mercury from the materials. After using the thermal method to evaporate mercury, the materials can be recycled because they contain almost mercury-free compounds. Distillation can be used only to recover mercury from mercury-contaminated materials. ${ }^{91,92}$ Mercury collected from the thermal method can be refined by distillation in many steps to obtain high-purity mercury. In the thermal method, recovery devices for mercury in gaseous phase should be used because mercury from contaminated materials is transferred to mercury vapor.

The treatment technology can also be categorized into two technical divisions. The first technical division is targeted to reduce the mobility and toxicity of the materials containing mercury with physicochemical processes, and the second technical division aims to store the mercury-containing materials safely.

The first technical division includes solidification, amalgamation, soil washing and acid extraction, as shown in Table $4{ }^{7,93-97}$ Stabilization is a process whereby additives are mixed with waste to minimize the rate of contaminant migration and to reduce the toxicity of waste with chemical reaction. Solidification is a process employing additives such as Portland cement and sulfur polymer by which the physical nature of the waste is altered. Solidification and stabilization $(\mathrm{S} / \mathrm{S})$ can be applied to waste consisting of elemental mercury and mercury compounds in solid phases (soil, sludge, ash) and in liquid phases (wastewater, leachate). S/S aims in reducing both the mobility and the hazard of mercury compounds by physically binding and encapsulating them. ${ }^{93}$ Amalgamation is a chemical process unique to elemental mercury, in which another metal forms a semisolid alloy, resulting in a nonvolatile product. Since mercury in amalgam can be susceptible to release by volatilization or leaching, amalgamation is typically used in combination with an encapsulation technology. ${ }^{98}$ Soil washing is a cleaning process for soil and sediment contaminated with mercury using water. This process is based on the concept that most contaminants tend to bind to the finer soil particles (clay and silt) rather than to the larger particles (sand and gravel). This process thus concentrates on the contamination bound to the finer particles. Acid extraction is used to extract mercury from a solid matrix by dissolving it in an acid such as hydrochloric acid or sulfuric acid. ${ }^{98}$

In the second technical division, permanent storage and secured landfill are included, as shown in Table 4..$^{7,98-100}$ Permanent storage of mercury-bearing wastes should ensure that these wastes are stored inside proper buildings, in a locked room, or in a partitioned area not in high use. The secured landfill can be used as a final disposal option for mercury-bearing waste containing residual mercury and not economically viable for recovery. The requirement for the final disposal is lining the waste material with impervious plastic sheeting to prevent leakage or leaching of mercury constituents into soil and groundwater. ${ }^{101-103}$

Table 4 Treatment methods of mercury-containing wastes

\begin{tabular}{|c|c|c|}
\hline Method & Explanation & Mercury waste \\
\hline $\begin{array}{l}\text { Stabilization and } \\
\text { solidification }\end{array}$ & $\begin{array}{l}\text { Stabilization processes include chemical reactions that may change the hazardous } \\
\text { characteristics of the waste (by reducing the mobility and toxicity of the waste constituents). } \\
\text { Solidification processes only change the physical state of the waste by using additives } \\
\text { (eg, liquid into solid) without changing the chemical properties of the waste (European } \\
\text { Commission). There are two main chemical approaches that can be applied to wastes } \\
\text { consisting of elemental mercury and wastes containing or contaminated with mercury: } \\
\text { a. Chemical conversion to mercury sulfide. } \\
\text { b. Amalgamation (formation of a solid alloy with suitable metals). }\end{array}$ & $\begin{array}{l}\text { Soil, sludge, ash, } \\
\text { liquid waste }\end{array}$ \\
\hline Soil washing & $\begin{array}{l}\text { Soil washing is an ex situ treatment of soil and sediment contaminated with mercury. } \\
\text { Physical methods can be used to separate the relatively clean larger particles from the } \\
\text { finer particles because the finer particles are attached to larger particles through physical } \\
\text { processes (compaction and adhesion). }\end{array}$ & Soil \\
\hline $\begin{array}{l}\text { Specially engineered } \\
\text { landfill }\end{array}$ & $\begin{array}{l}\text { Following stabilization or solidification, waste containing or contaminated with mercury that } \\
\text { meets the acceptance criteria for landfill may be disposed of in specially engineered landfills. } \\
\text { Some jurisdictions have defined acceptance criteria for landfilling of wastes containing or } \\
\text { contaminated with mercury. Particular attention should be paid to the measures required to } \\
\text { protect groundwater resources from leachate infiltration into the soil. }\end{array}$ & All mercury wastes \\
\hline Permanent storage & $\begin{array}{l}\text { Following solidification or stabilization, wastes containing or contaminated with mercury } \\
\text { which meet the acceptance criteria for permanent storage may be permanently stored in } \\
\text { special containers in designated areas such as an underground storage facility. }\end{array}$ & $\begin{array}{l}\text { Stabilize mercury } \\
\text { waste and radiation- } \\
\text { active waste }\end{array}$ \\
\hline
\end{tabular}


For mercury vapor, it has been recommended to use adsorption technology to capture the mercury with activated carbon or zeolites. This technique can be applied to the flue gas in combustion facilities and electric power plants. For elemental mercury and wastes contaminated with mercury in liquid and solid phases, it is desirable to recover the mercury in case of high concentration or to immobilize it in an environmentally sound manner.

\section{Future trends in mercury control technologies}

All countries in the world have a concern to control or reduce mercury usage and emissions of mercury because of the Minamata Convention on Mercury. Global Mercury Assessment in $\mathrm{UNEP}^{16}$ provided the most recent information regarding the worldwide emissions, releases, and transport of mercury in atmospheric and aquatic environments. The technical guidelines for the environmentally sound management of wastes consisting of elemental mercury and wastes containing or contaminated with mercury were published by the Basel Convention in 2012. ${ }^{7}$ US EPA has also been committed to a detailed mercury study report on the trends in mercury emission and mercury use. ${ }^{103}$ It has also initiated an international engagement with the UNEP global program and other regional mechanisms to reduce mercury in the environment. According to emission scenarios from the global mercury observation system (GMOS), ${ }^{104}$ mercury emissions from key selected sectors (those where mercury is an incidental pollutant and also the chlor-alkali industry) could drop by about $50 \%$ in 2020 if emission controls planned in Europe were to be extended worldwide. Since it will not be easy to extend the European plan of emission control to Asia, however, the emission scenarios may not be clear. In fact, several companies using mercury in Europe and North America have been moved to Asian countries such as the People's Republic of China, Indonesia, and Vietnam. Hence, the emission of mercury in Asia is increasing, while that in Europe and North America is decreasing.

With respect to the mercury control technologies, two general approaches for mercury control - software technologies and hardware technologies - have proven to be capable of effectively reducing mercury emissions to the regulatory levels.

Software technologies involve educational programs, monitoring systems, modeling technology for mercury fate and transport, material flow analysis (MFA) for mercury and mercury compounds, and life-cycle analysis (LCA) to reduce the emission of mercury from several sources into the environment. ${ }^{64,68,105}$ The educational programs should cover the production of mercury-added products, use of such products, collection and transportation of wastes, and disposal of wastes. Modeling technology is also very important to estimate the fate and transport of mercury in the future. MFA can identify the effect of mercury on the environment by showing the total consumption and the flow path of mercury. Specifically, the concept of LCA provides an important perspective for environmentally sound management of wastes consisting of elemental mercury and wastes containing or contaminated with mercury. LCA has provided a framework for analyzing and managing the performance of goods and services in terms of their sustainability. ${ }^{106}$

Using MFA and LCA for mercury and mercury compounds, it is important to prioritize the reduction of mercury used in products and processes to reduce the mercury content in wastes to be disposed of and in wastes generated from industrial processes. Through software technologies, the global partnership for the reduction of mercury and mercury compounds can be established by exchanging the information of reduction in each individual case study. The partnership can play an important role in the action on mercury reduction in industrial sectors in developing countries. Hence, the role of UNEP will be very important to support the work of the partnership and to take the lead on conducting additional activities understanding mercury pollution.

Several hardware technologies, such as pretreatment technology, recovery technology, and treatment technology, which were already explained in the previous section, can be developed by alternative processes to control mercury and mercury compounds efficiently because wastes containing mercury will be significantly restricted to dispose in landfill sites. Although it is difficult to develop the best available technology to reduce mercury and mercury compounds due to their different nature and physicochemical characteristics, several researches are being carried out to develop the best available technologies in a global concept. In the Basel Convention, ${ }^{7}$ several countries in the EU may try to classify hazardous waste containing mercury by total content of mercury instead of leaching concentration. Hence, distillation technology will be more powerful and advanced to recover mercury from mercury-containing wastes because other technologies such as $\mathrm{S} / \mathrm{S}$ and chemical precipitation may not be applied to remove mercury completely. Since the objective of $\mathrm{S} / \mathrm{S}$ was to prevent the release of the amount of mercury into the environment for a long time, mercury still existed in the products generated from $\mathrm{S} / \mathrm{S}$.

Adsorption technology with a special activated carbon as an adsorbent may be mainly used to control mercury 
vapor in the flue gas from combustion facilities and electric power plants. Since different types of activated carbon have different adsorption efficiencies, activated carbon for mercury adsorption has been impregnated by other materials such as sulfur, $\mathrm{Na}_{2} \mathrm{~S}, \mathrm{CuCl}_{2}, \mathrm{Co}_{3} \mathrm{O}_{4}, \mathrm{MnO}_{2}$, and $\mathrm{CuCoO}_{4}$ to control mercury efficiently. ${ }^{107,108}$ Moreover, the use of agricultural products and by-products has been widely investigated as a replacement for current adsorbents for removing mercury and mercury compounds from gas, water, and wastewater. ${ }^{109}$ Also, the best available adsorption technologies to control mercury emission will be considered by the performance and cost. Therefore, advanced adsorption technology and adsorption behavior on mercury will be developed by economic and environmental evaluations for the adsorbents with additives to prevent mercury release into the atmosphere.

In case the adsorption and thermal methods cannot be applied to wastes containing mercury, permanent storage and secured landfill should be used to control them in advanced methods. ${ }^{7,98,103}$ After S/S, the stabilized product should be subjected to the leaching test to verify whether it is a hazardous waste or not. ${ }^{97}$ If the stabilized product meets the acceptance criteria for solid waste by the leaching test, the stabilized product may be permanently stored in special containers in designated areas such as an underground storage facility. ${ }^{103}$ Wastes containing mercury that cannot meet the acceptance criteria for solid waste by the leaching test should be disposed in a secured landfill for hazardous wastes. Specific requirements of criteria regarding secured landfill for hazardous wastes should be satisfied with the field of site survey, design and construction, landfill operations, and monitoring in order to prevent leachate leakages and air pollution by landfill gas. ${ }^{54}$ Therefore, the technologies for permanent storage and secured landfill should be advanced to dispose of wastes containing mercury for long-term management.

Finally, the emergency response plans should be established for mercury and mercury compounds in production, in use, in storage, in transport, and in disposal sites. The guidelines or manuals for the emergency response plans should include site investigation, the characteristics of mercury and mercury compounds, and monitoring methods. Investigation of site should be necessary to ensure public safety for evacuating human resources and equipment and for isolating emergency areas. The characteristics of mercury and mercury compounds should be notified by identifying potential hazards, container labels, shipping documents, and material safety data sheets. And monitoring methods, including testing methods and emergency response equipment, should be practiced frequently to deal with emergency situations.

\section{Discussion and recommendations}

Recently, the Minamata Convention on Mercury and the UNEP Global Mercury Partnership have been very effective in raising awareness of mercury pollution issues in the world. In order to reduce mercury usage, regulations and guidelines for mercury and mercury products are established in many developed countries to contribute positively to mercury reduction in the world.

The review of mercury from anthropogenic sources and natural sources is very important to control mercury emission. With respect to the sources of mercury emission, the contribution from anthropogenic sources $(1,010-4,070$ ton/yr) is much less than that from natural sources (3,780-6,350 ton/yr). Nevertheless, the policies to control mercury and mercury products are focused on anthropogenic sources to reduce mercury emission efficiently. Oceans are the most important sources among natural sources, but mercury in oceans mostly come from anthropogenic sources such as mining activities, coal and oil combustion, cement production, and chlor-alkali plant. Mercury emission from natural sources cannot be controlled readily, while the mercury emission from anthropogenic sources can be controlled by several control policies and technologies. Hence, control of anthropogenic sources is very important to reduce mercury emission by phasing out mercury in the products. Owing to the phaseout of mercury in the products, mercury-containing products will be ultimately reduced, thereby reducing the mercury released into the atmosphere. It is important to implement the plan of phasing out mercury to achieve the goals on mercury elimination in consumer products. Also, it is recommended to gather data on mercury emissions from mercury-containing products during the production process, consuming period, and disposal process to evaluate the MFA on mercury and mercury compounds globally and locally. It should be realized that source control on mercury has contributed significantly and effectively to mercury reduction in the world.

The policies and regulations in advanced countries and developing countries are managed to control properly the mercury emission. In advanced countries, the legislative or regulatory framework on mercury emission has been adopted to eliminate mercury in mercury-containing products. The use of mercury in several measuring devices (eg, thermometers, sphygmomanometers, barometers) was restricted for industrial and professional uses. Hence, they can control mercury sources both in small- and in large-scale generators by the acts and regulations to eliminate mercury emission in the near future. In developing countries, however, there is no specific regulation on mercury emission even though mercury emission into atmosphere could be expected to increase because 
they use fossil fuels such as coal and crude oil in order to meet the growing energy demands. After the participation in the Minamata convention, developing countries such as the People's Republic of China, India, Indonesia, and Vietnam have tried to prepare a national mercury management to control mercury emission in public areas. The policies and regulations for mercury management in advanced countries may be beneficial to set up the framework of mercury management in the developing countries to prevent the mercury emission economically and technically.

Mercury control technologies such as pretreatment technology, recovery technology, and treatment technology are discussed to reduce the emission of mercury from various sources. Among mercury control technologies, pretreatment technology is very important to improve the purity of mercury. Hence, it is necessary to emphasize the use of pretreatment for mercury materials to recover mercury and its by-product. With respect to recovery and treatment technologies, different technologies can be applied to different phases of mercury generation, such as gaseous phase, liquid phase, and solid phase. Liquid and solid phases of mercury compounds should be treated to recover the mercury in case of high concentration or to immobilize it in an environmentally sound manner. Due to the Minamata Convention on Mercury and The UNEP Global Mercury Partnership, those technologies should be changed and advanced to control mercury and mercury compounds effectively. In order to develop alternative control processes such as mercury-free processes, advanced distillation technology, and adsorption, significant investment and effort on the control technologies are required. Hence, it is recommended that software technologies such as educational programs, modeling technology for mercury fate and transport, MFA for mercury and mercury compounds, and LCA should be applied initially to reduce the emission of mercury from several sources into the environment economically.

Comprehensive policies, life-cycle assessments, and public educational programs on mercury-free products should be developed to reduce mercury emissions from various sources. And best available technologies using advanced processes should be provided to control the mercury emission into the environment. Specifically, public education and outreach programs should be used to create a broad awareness of the significance of mercuryfree products, the necessity of recycling programs in households and industries, and the importance of MFA on mercury stream. In the public educational program, collecting system should be established to collect mercury products efficiently from consumers to recycling facilities. It is recommended that collection boxes are located near consumers to gather mercury-containing products properly and readily so as to help minimize their accidental emissions. Such efforts to control mercury emission into the atmosphere locally and globally will bring about reductions across a range of products, processes, and industries where mercury is used, released, or emitted.

\section{Conclusion}

Due to the Minamata Convention on Mercury, GMOS, and the Global Mercury Partnership, policies and regulations on mercury management in the world have been intensified to reduce the usage of mercury. According to the scenarios from GMOS, hence, mercury emissions from selected anthropogenic sources could be estimated to decrease by about $50 \%$ by 2020 . Since source control on mercury is very important to reduce the mercury emission, the implementation plan of source control on mercury should be established with the policy and regulation on mercury management. Also, the advanced control technologies, which can be classified into hardware technologies and software technologies, can be applied to reduce mercury emission from anthropogenic sources. Among hardware technologies, pretreatment technology may be more important than recovery technology and treatment technology to reduce the mobility and toxicity of the materials containing mercury. To develop the best available technology reducing mercury and mercury compounds, the different nature and physicochemical characteristics should be considered. With respect to software technology, the following are recommended: an educational program, modeling technology for mercury fate and transport, monitoring system, and MFA for mercury and mercury compounds to reduce the mercury emission from several anthropogenic sources into the environment. Specifically, monitoring systems should be activated in both domestic and international scales to improve the cooperation network for global mercury treaty with long-term observation and evaluation. Also, monitoring system, including testing methods, evaluation, and emergency responses, should be operated properly to deal with emergency situations. Finally, the Global Mercury Partnership between developed countries and developing countries should be intensified to provide information on the worldwide mercury emissions, releases, and transport into atmospheric and aquatic environments.

\section{Acknowledgment}

This study was partially supported by the R\&D Center for Valuable Recycling (Global-Top Environmental Technology Development Program) funded by the Ministry of Environment, Korea (Project No: GT-11-C-01-070-0). 


\section{Disclosure}

The author reports no conflicts of interest in this work.

\section{References}

1. United Nations Environmental Programme. The global atmospheric mercury assessment: sources, emissions, and transport. Geneva, Switzerland: United Nations Environmental Programme, Division of Technology, Industry and Economics (DTIE), Chemicals Branch; 2008.

2. Technical background report for the global mercury assessment. Geneva, Switzerland: Arctic Monitoring and Assessment Programme, United Nations Environmental Programme; 2013.

3. Jarvis A, Maag J. Study on EU implementation of the Minamata convention on mercury. Bipro, Garrigues. June 30, 2014.

4. Mishima A, Brown LR. Bitter Sea: The Human Cost of Minamata Disease. Tokyo, Japan: Kosei Publishing; 1992.

5. Jesty J. Making mercury visible: the Minamata documentaries of Tsuchimoto Noriaki. In: Zuber SL, Newman MC, editors. Mercury Pollution: A Transdisciplinary Treatment. 1st ed. Boca Raton, FL: CRC Press; 2011.

6. Lessons from Minamata disease and mercury management in Japan. Ministry of the Environment, Japan; 2013

7. Basel convention technical guidelines. United Nations Environmental Programme, Basel Convention; 2011.

8. Authenticated United States Government Information. Public law 110-414 - Oct 2008;154(110-477).

9. Emmott N, Slayne M. Legislation and policy concerning mercury in the European Union. In: Pirrone N, Mahaffey KR, editors. Dynamics of Mercury Pollution on Regional and Global Scales. Berlin, Germany: Springer; 2005:65-80.

10. European Commission. Regulation (EC) No 244/2009 implementing directive 2005/32/EC of the European Parliament and of the Council with regard to ecodesign requirements for non-directional household lamps. Official Journal of the European Union. March 18, 2009.

11. Ziegler O. Waste electrical and electronic equipment. In: EU Regulatory Decision Making and the Role of the United States. Berlin, Germany: Springer; 2013:93-141.

12. Guide for negotiators of multilateral environmental agreements. United Nations Environmental Programme. 2007. Available from: http://www. unep.org/publications/contents/pub_details_search.asp?ID=3925. Accessed August 27, 2014.

13. United Nations Environmental Programme. Study on mercury sources and emissions, and analysis of cost and effectiveness of control measures "UNEP Paragraph 29 study". Geneva, Switzerland: UNEP, Division of Technology, Industry and Economics (DTIE), Chemicals Branch; Nov 2010.

14. Pirrone N, Cinnirella S, Feng X, et al. Global mercury emissions to the atmosphere from anthropogenic and natural sources. Atmospheric Chemistry and Physics. 2010;10:5951-5964.

15. Mason RP. Mercury emissions from natural processes and their importance in the global mercury cycle. In: Mason R, Pirrone N, editors. Mercury Fate and Transport in the Global Atmosphere. Berlin, Germany: Springer; 2009:173-191.

16. United Nations Environmental Programme. Global mercury assessment 2013: sources, emissions, releases, and transport. Geneva, Switzerland: United Nations Environmental Programme, Division of Technology, Industry and Economics (DTIE), Chemicals Branch; 2013.

17. Gaffney JS, Marley NA. In-depth review of atmospheric mercury: sources, transformations, and potential sinks. Energy Emission Control Technol. 2014;2:1-21.

18. Friedli HR, Radke LF, Lu JY, Banic CM, Leaitch WR, MacPherson JI. Mercury emissions from burning of biomass from temperate North American forests: laboratory and airborne measurements. Atmos Environ. 2003;37:253-267.

19. Cinnirella S, Pirrone N. Spatial and temporal distributions of mercury emissions from forest fires in Mediterranean region and Russian federation. Atmos Environ. 2006;40:7346-7361.
20. Ebinghaus R, Slemr F, Brenninkmeijer CAM, et al. Emissions of gaseous mercury from biomass burning in South America in 2005 observed during Caribic flights. Geophys Res Lett. 2007;34(8):1-5. doi:10.1029/2006GL028866.

21. Wiedinmyer C, Friedli H. Mercury emission estimates from fires: an initial inventory for the United States. Environ Sci Technol. 2007;41:8092-8098.

22. Nriagu J, Becker C. Volcanic emissions of mercury to the atmosphere: global and regional inventories. Sci Total Environ. 2003;304:3-12.

23. Pyle DM, Mather TA. The importance of volcanic emissions for the global atmospheric mercury cycle. Atmos Environ. 203;37: 5115-5124.

24. Ferrara R, Mazzolai B, Lanzillotta E, Nucaro E, Pirrone N. Volcanoes as emission sources of atmospheric mercury in the Mediterranean basin Sci Total Environ. 2000;259:115-121.

25. Pirrone N, Costa P, Pacyna JM, Ferrara R. Mercury emissions to the atmosphere from natural and anthropogenic sources in the Mediterranean region. Atmos Environ. 2001;35:2997-3006.

26. Mason RP, Sheu GR. Role of the ocean in the global mercury cycle. Global Biogeochem Cycles. 2002;16(4):40-1-40-14. doi:10.1029/2001GB001440.

27. Hedgecock IM, Pirrone N, Trunfio GA, Sprovieri F. Integrated mercury cycling, transport, and air-water exchange (MECAWEx) model J Geophys Res. 2006;(D20,27):1-13.doi:10.1029/2006JD007117.

28. United Nations. Emissions. In: Pirrone N, Keating T, editors. Hemispheric Transport of Air Pollutants Part B: Mercury. Geneva, Switzerland: United Nations; 2011:75-96. HTAP 2010 Assessment Report.

29. Zagar D, Petkovsek G, Rajar R, et al. Modelling of mercury transport and transformations in the water compartment of the Mediterranean Sea. Marine Chem. 2007;107:64-88.

30. Mason RP, Choi AL, Fitzgerald WF, et al. Mercury biogeochemical cycling in the ocean and policy implications. Environ Res. 2012;119:101-117.

31. Pirrone N, Cinnirella S, Feng X, et al. Global mercury emissions to the atmosphere from natural and anthropogenic sources. In: Pirrone N, Mason R, editors. Mercury Fate and Transport in the Global Atmosphere. Berlin, Germany: Springer; 2009:3-49.

32. Feng X. Mercury pollution in China - an overview. In: Pirrone N, Mahaffey KR, editors. Dynamics of Mercury Pollution on Regional and Global Scales. Berlin, Germany: Springer; 2005:657-678.

33. Pacyna EG, Pacyna JM, Steenhuisen F, Wilson S. Global anthropogenic mercury emission inventory for 2000. Atmos Environ. 2006; 40:4048-4063.

34. Feng X, Streets D, Hao J, Wu Y, Li G. Mercury emissions from industrial sources in China. In: Mason R, Pirrone N, editors. Mercury Fate and Transport in the Global Atmosphere. Berlin, Germany: Springer; 2009:67-79.

35. Fu X, Feng X, Sommar J, Wang S. A review of studies on atmospheric mercury in China. Sci Total Environ. 2012;421-422:73-81.

36. Hu D, Zhang W, Chen L, et al. Mercury emissions from waste combustion in China from 2004 to 2010. Atmos Environ. 2012;62:359-366.

37. Cheng H, Hu Y. Mercury in municipal solid waste in China and its control: a review. Environ Sci Technol. 2012;46:593-605.

38. Wilhelm SM. Estimate of mercury emissions to the atmosphere from petroleum. Environ Sci Technol. 2001;35:4704-4710.

39. Mukherjee AB, Bhattacharya P, Sarkar A, Zevenhoven R. Mercury emissions from industrial sources in India and its effects in the environment. In: Mason R, Pirrone N, editors. Mercury Fate and Transport in the Global Atmosphere. Berlin, Germany: Springer; 2009:81-112.

40. EU legislation on export/storage/disposal of mercury. Brasilia: Spanish Ministry of Agriculture, Food and Environmental; May 2012.

41. Boone T, Ganeshan R. A primer on E-waste. In: Boone T, Jayaraman V, Ganeshan R, editors. Sustainable Supply Chains. Vol 174. Berlin, Germany: Springer; 2012:107-127.

42. Selin NE, Selin H. Global politics of mercury pollution: the need for multi-scale governance. RECIEL. 2006;15(3):258-269. 
43. European Union. Directive 2012/19/EU of the European parliament and of the council of July 4, 2012 on waste electrical and electronic equipment (WEEE). Official Journal of the European Union. 2012;55. doi:10.3000/19770677.L_2012.197.eng.

44. European Environmental Bureau. Environmental NGOs response to stakeholder consultation on mercury-containing lamps - exemptions 7,8,9 (review of annex to the RoHS directive). September 4, 2012. Available from: http://rohs.exemptions.oeko.info/fileadmin/user_upload/RoHS_VI/ General_contributions/20120904_EEEB_ZMWG_RoHS_Stakeholder_ consultation_Ex_No_7_8_9.pdf. Accessed October 21, 2014.

45. Rafaj P, Cofala J, Kuenen J, Wyrwa A, Zysk J. Modeling the impact of European renewable energy policies on emissions of mercury. In: Page B, Fleischer AG, Wohlgemuth V, editors. EnviroInfo 2013. Aachen, Germany: Shaker; 2013:503-513.

46. United States Environmental Protection Agency. Locating and estimating air emissions from sources of mercury and mercury compounds. December 1997. Available from: http://www.epa.gov/ttn/chief/le/ mercury.pdf. Accessed October 21, 2014.

47. United States Environmental Protection Agency. National emission standards for hazardous air pollutants from coal- and oil-fired electric utility steam generating units and standards of performance for fossilfuel-fired electric utility, Industrial-Commercial-Institutional, and small industrial-commercial-institutional steam generating units. 2011.

48. Implementation of the mercury-containing and rechargeable battery management act. Washington, DC: United States Environmental Protection Agency; Nov 1997. Available from: http://www.epa.gov/ epawaste/hazard/recycling/battery.pdf. Accessed October 21, 2014.

49. Lambert KF, Evers DC, Warner KA, King SL, Selin NE. Integrating mercury science and policy in the marine context: challenges and opportunities. Environ Res. 2012;119:132-142.

50. Stephenson JB. Hazardous waste: EPA needs to clarify the types of mercury waste that can be treated and disposed of using the debris regulations. GAO-6-99. 2005:1-58. Available from: http://www.gao. gov/assets/250/248832.pdf. Accessed October 21, 2014.

51. United States Environmental Protection Agency. Addressing mercury releases. In: EPA's roadmap for Mercury. Jul 2006:21-33. Available from: http://www.epa.gov/mercury/archive/roadmap/pdfs/__HgReleases.pdf. Accessed October 21, 2014.

52. United States Environmental Protection Agency. EPA's roadmap for mercury. Jul 2006. Available from: http://www.epa.gov/mercury/ archive/roadmap/pdfs/FINAL-Mercury-Roadmap-6-29.pdf. Accessed October 21, 2014.

53. United States Environmental Protection Agency. RCRA training module, introduction to universal waste. September 2005. Available from: http://www.epa.gov/epawaste/inforesources/pubs/training/uwast05.pdf. Accessed October 21, 2014.

54. United States Environmental Protection Agency. RCRA training module, introduction to land disposal restrictions (40 CFR part 268). September 2005. Available from: http://www.epa.gov/epawaste/inforesources/pubs/ training/ldr05.pdf. Accessed October 21, 2014.

55. Schierow LJ. The toxic substances control act (TSCA): a summary of the act and its major requirements. Congressional Research Service Report; April 1, 2013. Available from: http://fas.org/sgp/crs/misc/RL31905.pdf. Accessed October 21, 2014.

56. Tiemann M. Safe drinking water act (SDWA): a summary of the act and its major requirements. Congressional Research Service Report. February 5, 2014. Available from: http://fas.org/sgp/crs/misc/RL31243. pdf. Accessed October 21, 2014.

57. Porter BO. Division of pulmonary, allergy, and rheumatology products medical officer consultation. April 22, 2010. Available from: http://www. fda.gov/downloads/AdvisoryCommittees/CommitteesMeetingMaterials/ MedicalDevices/MedicalDevices AdvisoryCommittee/ DentalProductsPanel/UCM236366.pdf. Accessed October 21, 2014.

58. Minister of Justice. Canadian Environmental Protection Act, 1999. July 22, 2014. Available from: http://laws-lois.justice.gc.ca. Accessed August $19,2014$.
59. Minister of Justice. Chlor-Alkali Mercury Liquid Effluent Regulations. C.R.C., c. 811. July 22, 2014. Available from: http://laws-lois.justice. gc.ca. Accessed August 19, 2014.

60. Hu Y, Cheng H. Mercury risk from fluorescent lamps in China: current status and future perspective. Environ Internat. 2012;44:141-150.

61. China Council for International Cooperation on Environment and Development, part 1: CCICED 2011 Annual General Meeting, Special Policy Study on Mercury Management in China. 2011:409-463. Available from: http://www.cciced.net/encciced/policyresearch/report/201205/ P020120529368288424164.pdf. Accessed October 21, 2014.

62. Agrawal A. Moving towards mercury-free health care: substituting mercury-based medical devices in India. Toxics Link. 2009.

63. Creating networks and information for mercury policy in India and Europe. Toxics Link. 2005.

64. Chakraborty LB, Qureshi A, Vadenbo C, Hellweg S. Anthropogenic mercury flows in India and impacts of emission controls. Environ Sci Technol. 2013;47:8105-8113.

65. Ministry of the Environment, Japan. Lessons from Minamata disease and mercury management in Japan. Tokyo, Japan. Jan 2011. Available from: http://www.env.go.jp/en/focus/docs/files/20110101-39.pdf. Accessed October 21, 2014.

66. Ministry of the Environment, Japan. Waste management and public cleansing law. 2001. Available from: https://www.env.go.jp/en/laws/ recycle/01.pdf. Accessed October 21, 2014

67. Ministry of the Environment, Japan. Lessons from Minamata disease and mercury management in Japan. Tokyo, Japan. Sep 2013. Available from: http://www.env.go.jp/chemi/tmms/pr-m/mat01/en_full.pdf. Accessed October 21, 2014

68. Jang E, Kim K-R, Kim K-H, Hur T. Material flow analysis and human risk assessment of mercury. In: Matsumoto M, Umeda Y, Masui K, Fukushige S, editors. Design for Innovative Value Towards a Sustainable Society. Berlin, Germany: Springer; 2012:888-890.

69. Lee SJ, Seo YC, Jurng JS, et al. Mercury emissions from selected stationary combustion sources in Korea. Sci Total Environ. 2004;325:155-161.doi:10.1016/j.scitotenv.2003.12.002.

70. Min DK, Rhee SW. Management of municipal solid waste in Korea. In: Pariatamby A, Tanaka M, editors. Municipal Solid Waste Management in Asia and the Pacific Islands. Berlin, Germany: Springer; 2014:173-194.

71. Rhee SW, Choi HH, Park HS. Performance evaluation of material separation from spent fluorescent lamps using the thermal end-cutting method. J Mater Cycles Waste Manage. 2013;15(4):503-509.

72. Rhee SW, Choi HH, Park HS. Characteristics of mercury emission from linear type of spent fluorescent lamp. Waste Manage. 2014;34:1066-1071.

73. Society of Solid Waste Management Experts in Asia and Pacific Islands. Appropriate management of mercury waste. In: Proceedings of the 13th SWAPI meeting special symposium; Kyoto University; March 11, 2014; Japan.

74. Hajeb P, Jinap S, Ismail A, Mahyudin NA. Mercury pollution in Malaysia. In: Whitacre DM, editor. Reviews of Environmental Contamination and Toxicology. Berlin, Germany: Springer; 2012;220: 45-66.

75. Vesilind PA, Warrell WA, Reinhark DR. Materials Separation. In: Solid Waste Engineering. Pacific Grove, CA: BooksCole; 2002:224-277.

76. Jang M, Hong SM, Park JK. Characterization and recovery of mercury from spent fluorescent lamps. Waste Manage. 2005;25:5-14.

77. Nomura Kohsan Co, Ltd. Treatment of Mercury-containing Wastes at Itomuka plant of Nomurakohsan Co, Ltd. Tokyo, Japan. 2007.

78. United States Environmental Protection Agency. Locating and estimating air emissions from sources of mercury and mercury compounds. 1997. Available from: http://www.epa.gov/ttn/chief/le/mercury.pdf. Accessed August 27, 2014.

79. Iverfeldt A, Lindqvis $\mathrm{O}$. Atmospheric oxidation of elemental mercury by ozone in the aqueous phase. Atmos Environ. 1986;20(8):1567-1573.

80. Munthe J. The aqueous oxidation of elemental mercury by ozone. Atmos Environ. Part a - General Topics. 1992;26(8):1461-1468. 
81. Norton GA, Yang H, Brown RC, Laudal DL, Dunham GE, Erjavec J. Heterogenous oxidation of mercury in simulated post combustion conditions. Fuel. 2003;82(2):107-116.

82. Presto AA, Granite EJ, Karash A, Hargis RA, O’Dowd WJ, Pennline HW. A kinetic approach to the catalytic oxidation of mercury in flue gas. Energy Fuels. 2006;20(5):1941-1945.

83. Zhang H. Photochemical redox reactions of mercury. In: Atwood DA, editor. Recent Developments in Mercury Science. Berlin, Germany: Springer; 2006;120:37-79.

84. United states environmental Protection Agency. Mercury treatment technologies. 2007. Available form: http://www. cluin.org/contaminantfocus/default.focus/sec/Mercury/cat/ Treatment_Technologies. Accessed August 27, 2014.

85. United States Environmental Protection Agency. Treatment technologies for mercury in soil, waste and water. 2007. Available from: http:// www.epa.gov/tio/download/remed/542r07003.pdf. Accessed August 27, 2014.

86. Musmarra D, Karatza D, Lancia A, Prisciandaro M, Celso GMD. Adsorption of mercury chloride onto activated carbon on a new pilot scale plant. Chem Eng Trans. 2013;32:574-552.doi:10.3303/ CET1332092.

87. Luo J, Hein AM, Hwang JY. Adsorption of vapor phase mercury on various carbons. J Minerals Mater Characterization Eng. 2004;3(1):13-22.

88. Chang TC, Yen JH; Univ of Technology, Taipei, Taiwan. On-site mercury-contaminated soils remediation by using thermal desorption technology. J Hazardous Mater. 2006;128(2-3):208-217.

89. Busto Y, Cabrera X, Tack FMG, Verloo MG. Potential of thermal treatment for decontamination of mercury containing wastes from chlor-alkali industry. J Hazardous Mater. 2011;186:114-118.

90. Jones CJ, NcGugan PJ. Evaporation of mercury from domestic waste leachate. J Hazardous Mater. 1972;78(2):253-258.

91. United States Environmental Protection Agency. Workshop on mercury in products, processes, waste and the environment: eliminating, reducing and managing risks from non-combustion sources. Treatment and Disposal Options, Proceedings and Summary Report; 2001. Available from: http://www.clu-in.org/download/contaminantfocus/mercury/ workshop-on-mercury-in-products.pdf. Accessed October 21, 2014.

92. United States Environmental Protection Agency. Methyl mercury in water by distillation, aqueous ethylation, purge and trap, and cold vapor atomic fluorescence spectrometry. Method 1630. Aug 1998.

93. European Commission. Commission Decision of 3 May 2000 replacing decision 94/3/EC establishing a list of wastes pursuant to article 1(a) of council directive 75/442/EEC on waste and Council decision 94/904/EC establishing a list of hazardous waste pursuant to Article 1(4) of council directive 91/689/EEC on hazardous waste. 2003.

94. Hagemann S. Technologies for the stabilization of elemental mercury and mercury-containing wastes. Global Res Safety. 2009:252 Available from: http://www.grs.de/sites/default/files/pdf/GRS\%20\%20252_0.pdf. Accessed October 21, 2014.
95. Piao H, Bishop PL. Stabilization of mercury-containing wastes using sulfide. EnvironPollut. 2006;139:498-506.

96. Randall PM, Chattopadhyay S. Bench-scale evaluation of chemically bonded phosphate ceramic technology to stabilize mercury waste mixtures. J Environ Eng. Mar 2010:265-273.

97. Randall P, Chattopadhyay S. Advances in encapsulation technologies for the management of mercury-contaminated hazardous wastes. J Hazardous Mater. 2004;B114:211-223.

98. United States Environmental Protection Agency. Treatment technologies for mercury in soil, waste, and water. Aug 2007. Available from: http://www.epa.gov/tio/download/remed/542r07003.pdf. Accessed October 21, 2014.

99. Yang JX, Zhang MX, Li XL. Mercury pollution characteristics in the soil around landfill. In: Lin S, Huang X, editors. Advances in Computer Science, Environment, Ecoinformatics, and Education. Berlin, Germany: Springer; 2011;214:336-340.

100. Dookhun V, Mahadeo K. Assessment of mercury pollution at mare Chicose landfill in Mauritius. In: Bhowon MG, Sabina JL, Wah HLK, Ramasami P, editors. Chemistry Education in the ICT Age. Berlin, Germany: Springer; 2009:427-435.

101. BiPRO GmbH. Requirements for facilities and acceptance criteria for the disposal of metallic mercury. BiPRO GmbH Reports; April 16, 2010.

102. Department of Energy and Climate Change. Guidance document for the offshore industry on commission regulation (EC) No 1102/2008 on the banning of exports and safe storage of metallic mercury. Mar 2013.

103. United States Department of Energy. Long-term management and storage of elemental mercury. 2010.

104. Global mercury observation system. 2014. Available from: http://www. gmos.eu/. Accessed October 21, 2014.

105. Apisitpuvakul W, Piumsomboon P, Watts DJ, Koetsinchai W. LCA of spent fluorescent lamps in Thailand at various rates of recycling. J Cleaner Product. 2008;16:1046-1061.

106. United Nations Environment Programme. Society of environmental toxicology and chemistry. Life cycle management. 2009. Available form: http://www.unep.fr/shared/publications/pdf/DTIx1208xPALifeCycleApproach-Howbusinessusesit.pdf. Accessed August 27, 2014.

107. Clercq JD. Removal of mercury from aqueous solutions by adsorption on a new ultra stable mesoporous adsorbent and on a commercial ion exchange resin. Internat J Industrial Chem. 2012;3(1):1-6.

108. Hsi HC, Rood MJ, M.ASCE2, Massoud RA, Chen S, Chang R. Mercury adsorption properties of sulfur-impregnated adsorbents. $J$ Environ Eng. Nov 2002:1080-1089. doi:10.1061/(ASCE)07339372(2002)128:11(1080).

109. Khaloo SS, Matin AH, Sharifi S, Fadaeinia M, Kazempour N, Mirzadeh S. Equilibrium, kinetic and thermodynamic studies of mercury adsorption on almond shell. Water Sci Technol. 2012;65(8): 1341-1349.
Energy and Emission Control Technologies

\section{Publish your work in this journal}

Energy and Emission Control Technologies is an international, peer-reviewed, open access journal publishing original research, reviews, editorials and commentaries on developing technologies to optimize energy production and control of emissions. The manuscript management system is completely online and includes

\section{Dovepress}

a very quick and fair peer-review system, which is all easy to use. Visit http://www.dovepress.com/testimonials.php to read real quotes from published authors. 